\title{
ANALISIS STABILITAS TIMBUNAN DI ATAS KONSTRUKSI TIANG DAN GEOSINTETIK MENGGUNAKAN PROGRAM ELEMEN HINGGA
}

\author{
Yosia Firmansyah $^{1}$ dan Andryan Suhendra ${ }^{2}$ \\ ${ }^{1}$ Program Studi Sarjana Teknik Sipil, Universitas Tarumanagara, Jl. Letjen S. Parman No.1 Jakarta \\ yosia.firmansyah@gmail.com \\ ${ }^{2}$ Program Studi Sarjana Teknik Sipil, Universitas Tarumanagara, Jl. Letjen S. Parman No.1 Jakarta \\ andryansuhendra@yahoo.com
}

Masuk: 10-07-2020, revisi: 19-07-2020, diterima untuk diterbitkan: 05-08-2020

\begin{abstract}
Soft soil is a challenge for a geotechnical engineer due to soil characteristics that can cause various problems in the construction process. Geosynthetic reinforcement will be used on piles to replace concrete slabs and improve undesirable soft soil characteristics. This research will use the BS 8006 method and the 3D finite element program that uses the finite element method to compare the geosynthetic tensile strength and how geosynthetic influences the embankment on the pile. The study will also see the magnitude of the increase in safety factors and landslide patterns in the subgrade calculated by the program. This is done because the BS 8006 calculation method does not take into account the subgrade in analyzing the geosynthetic tensile strength while the calculation of the finite element-based program will increase the accuracy of the calculations to be performed in this study. this geosynthetic material has been proven to reduce slippage and channel load to the pile. This reinforcement and geosynthetic reinforcement can increase the safety factor of the embankment by at least 0.35 and the greatest increase is 2,242.
\end{abstract}

Keywords: geosynthetic; safety factor; 3D software; embankment on pile; soft soil

\begin{abstract}
ABSTRAK
Tanah lunak merupakan tantangan bagi seorang engineer geoteknik dikarenakan karakteristik tanah yang dapat menyebabkan berbagai masalah dalam proses konstruksi. Perkuatan geosintetik akan digunakan pada tiang untuk menggantikan slab beton dan memperbaiki karateristik tanah lunak yang tidak diinginkan. Penelitian ini akan menggunakan metode BS 8006 dan program elemen hingga 3D yang menggunakan metode elemen hingga untuk membandingkan kuat tarik geosintetik dan bagaimana geosintetik mempengaruhi timbunan yang ada di atas tiang. Penelitian juga akan melihat besarnya peningkatan safety factor dan pola kelongsoran pada tanah dasar hasil perhitungan program. Hal ini dilakukan karena metode perhitungan BS 8006 tidak memperhitungkan tanah dasar dalam menganalisa kuat tarik geosintetik sedangkan perhitungan program berbasis elemen hingga 3D akan memperbesar keakuratan pada perhitungan yang akan dilakukan pada penelitian ini. material geosintetik ini terbukti dapat mengurangi kelongsoran dan menyalurkan beban timbunan ke tiang. Perkuatan tiang dan geosintetik ini dapat meningkatkan faktor keamanan timbunan setidaknya sebesar 0,35 dan peningkatan yang paling besar adalah 2.242 .
\end{abstract}

Kata kunci: geosintetik; faktor keamanan; program elemen hingga 3D; timbunan di atas tiang; tanah lunak.

\section{PENDAHULUAN}

Konstruksi fondasi di atas tanah lunak sering kali menimbulkan berbagai permasalahan seperti daya dukung yang rendah serta penurunan yang besar. Dikarenakan tanah lunak dapat menyebabkan kelongsoran pada tanah. Banyak metode yang dapat digunakan untuk mendesain fondasi pada tanah lunak, seperti penggunaan geosintetik, vertikal drain, dan sebagainya. Salah satu teknik yang dapat digunakan adalah timbunan di atas tiang (piled embankment)

Piled Embankment merupakan suatu metode yang digunakan untuk menimbun tanah lunak di atas tiang. slab beton biasanya digunakan untuk menyalurkan gaya-gaya yang terjadi akibat timbunan kepada Piled Embankment. Namun slab beton memiliki komponen yang terdiri dari besi dan beton yang dapat menyebabkan kenaikan biaya yang besar, geosintetik dapat digunakan untuk menggantikan slab beton. 
Geosintetik merupakan material sintetik yang popular digunakan untuk proyek konstruksi tanah. Geosintetik dapat terdiri dari geotekstil, geogrid, geofabric, geomembrane, geocell, dan sebagainya. Pemakaian geosintetk akan disesuaikan dengan tujuan dan kondisi tanah dipakainya geosintetik.

Geosintetik digunakan untuk menyalurkan gaya-gaya yang terjadi diatas kepada tiang-tiang di bawahnya. Selain untuk menyalurkan beban, geosintetik juga berfungsi untuk memberikan kekuatan pada timbunan, mencegah penurunan yang tidak merata, dan meningkatkan stabilitas tanah.

Dalam skripsi ini, penulis akan menganalisa pengaruh geosintetik pada stabilitas konstruksi timbunan diatas tiang (piled embankment) menggunakan program elemen hingga 3D berbasiskan elemen hingga.

Batasan masalah dalam penelitian ini antara lain:

1. Perhitungan stabilitas timbunan (safety factor, kuat tarik geosintetik)

2. Penelitian dilakukan pada salah satu proyek pelebaran jalan tol di Jakarta

3. Perhitungan dengan variasi jarak $(0,5 \mathrm{~m}, 1 \mathrm{~m}, 1,5 \mathrm{~m})$

4. Perhitungan dengan variasi ukuran pada tiang $(15 \mathrm{~cm}, 20 \mathrm{~cm}, 25 \mathrm{~cm})$

5. Penurunan tidak ditinjau.

Rumusan masalah yang akan dibahas pada penelitian ini adalah:

1. Analisa penggunaan kombinasi antara tiang pancang dengan material geosintetik dalam menanggulangi permasalahan timbunan di atas tanah lunak.

Tujuan dari penelitian ini adalah:

1. Mengetahui penggunaan kombinasi optimum antara tiang pancang dengan material geosintetik dalam menanggulangi stabilitas timbunan di atas tanah lunak.

2. Membandingkan hasil analisa stabilitas timbunan dengan menggunakan program elemen hingga 3D dan metode $B S 8006$.

\section{Piled embankment}

Pada umumnya, piled embankment memerlukan slab beton yang besar dan jarak antar tiang yang kecil. Hal ini dilakukan untuk mentransfer gaya-gaya kepada tiang and menghindari deformasi. Piled embankment yang menggunakan pelat beton memerlukan tulangan yang banyak tebal pelat beton yang besar untuk menahan gaya lateral yang besar. Hal ini menyebabkan kenaikan harga yang tidak praktis digunakan.

Geosintetik memiliki daya dukung tarik yang besar yang tidak dimiliki oleh tanah lunak. Geosintetik dapat mengurangi penurunan tanah, meningkatkan bearing capacity dan stabilitas slope ketika digunakan pada tanah lunak. Piled embankment yang menggunakan geosintetik akan menambahkan efisiensi transfer beban dari tanah ke tiang tanpa memberikan penambahan defleksi pada pelat. Lapisan geosintetik juga memberikan ketahanan lateral pada ujung embankment. Hal-hal tersebut yang menyebabkan piled embankment yang menggunakan geosintetik lebih sering dipakai daripada menggunakan pelat beton.

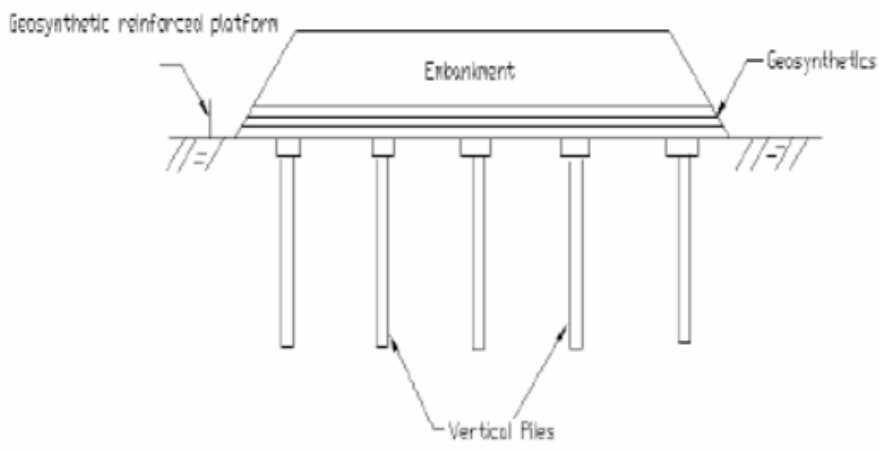

Gambar 1. Piled embankment dengan menggunakan geosintetik (Gangakhedkar, 2004)

\section{Arching theory}

Kelengkungan merupakan sebuah fenomena dimana beban disalurkan ke elemen yang lebih kuat/kaku. Tanah yang berada di antara tiang akan berkurang, namun tanah yang berada di atas tiang tidak dapat menetap dan akan memberikan ketahanan kepada tanah yang berkurang. Hal ini menyebabkan gaya geser dan menimbulkan lengkungan. 
Ketika geosintetik yang sangat lemah digunakan, tanah timbunan akan mengendap di antara tiang, menyebabkan gaya geser dan kelengkungan terbentuk. Gaya geser mengurangi gaya yang ditanggung geosintetik, tetapi gaya yang ditanggung pile cap meningkat. Lain hal nya, ketika geosintetik yang sangat kaku dipakai, gaya tarik pada perkuatan geosintetik akan menjadi sangat besar dan perpindahan yang sangat kecil. (Boogert, 2011)

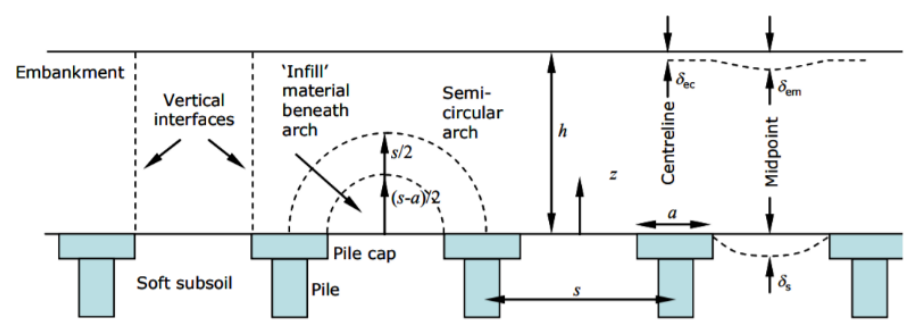

Gambar 2. Potensi kelengkungan tanah pada tanah timbunan di atas (Zhuang, 2009)

\section{Metode perhitungan BS 8006}

BS 8006 adalah metode British Standard (2010) yang digunakan untuk mendesain perkuatan fondasi pada tanah lunak. Ini adalah metode desain yang umum digunakan dan sangat konservatif. Beban distribusi vertikal yang bekerja pada perkuatan antara pile caps dapat dihitung dengan rumus berikut:

Untuk $\mathrm{H}>1,4 \times(\mathrm{s}-\mathrm{a})$

$$
\mathrm{W}_{\mathrm{T}}=\frac{1,4 . s . f f s \cdot \gamma \cdot(s-a)}{s^{2}-a^{2}} x\left(s^{2}-a^{2}\left(\frac{P c}{\sigma v}\right)\right)
$$

Untuk $0,7(\mathrm{~s}-\mathrm{a}) \leq \mathrm{H} \leq 1,4(\mathrm{~s}-\mathrm{a})$

$$
\mathrm{W}_{\mathrm{T}}=\frac{s \cdot(f f s \cdot \gamma \cdot \mathrm{H}+\mathrm{fq} \cdot \mathrm{WS})}{s^{2}-a^{2}} x\left(s^{2}-a^{2}\left(\frac{P c}{\sigma v}\right)\right)
$$

Tetapi $\mathrm{W}_{\mathrm{T}}=0 ;$ jika $\frac{s^{2}}{a^{2}} \leq\left(\frac{P c}{\sigma v}\right)$

dengan $\mathrm{s}=$ jarak antar 2 tiang, $\mathrm{a}=$ ukuran pile cap, $\mathrm{w}_{\mathrm{s}}=$ distribusi beban tambahan, $\mathrm{p}_{\mathrm{c}}=$ tegangan vertikal pada pile cap, $\sigma^{\prime}{ }_{\mathrm{v}}=$ faktor rata-rata tegangan vertikal pada dasar timbunan, $\mathrm{f}_{\mathrm{fs}}=$ faktor beban parsial untuk berat unit tanah, $\mathrm{f}_{\mathrm{q}}=$ faktor beban parsial untuk beban luar, $\mathrm{H}=$ tinggi timbunan.

Berdasarkan BS 8006 (2010), gaya tarik $\left(\mathrm{T}_{\mathrm{rp}}\right)$ yang dihasilkan dalam perkerasan berdasarkan distribusi gaya $\mathrm{W}_{\mathrm{T}}$ dapat dihitung menggunakan rumus berikut:

$$
\mathrm{T}_{\mathrm{rp}}=\frac{W T(s-a)}{2 a} \sqrt{1+\frac{1}{6 \varepsilon}}
$$

dengan $\mathrm{T}_{\mathrm{rp}}=$ tegangan pada perkerasan, $\mathrm{E}=$ regangan pada perkerasan, $\mathrm{WT}=$ beban total yang bekerja pada timbunan.

Perkerasan pada timbunan harus mampu menahan geser lateral yang disebabkan oleh gaya horizontal. gaya ini harus disesuaikan dengan regangan pada tiang. tegangan yang diperlukan dapat dihitung menggunakan rumus berikut:

$$
\mathrm{Tds}=0,5 \cdot K a \cdot(f f s \cdot \gamma \cdot H+2 \cdot f q \cdot w s) \cdot H
$$

dengan $\mathrm{T}_{\mathrm{ds}}=$ tegangan untuk menahan gaya horizontal, $\mathrm{K}_{\mathrm{a}}=$ koefisien tekanan tanah aktif, $\gamma=$ berat jenis tanah, $\mathrm{w}_{\mathrm{s}}$ = beban distribusi tambahan. 


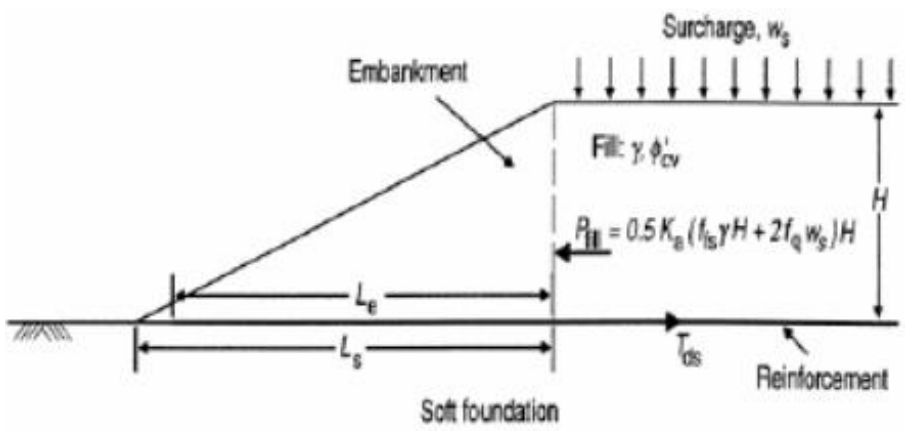

Gambar 3. Stabilitas geser lateral antara timbunan dengan perkerasan (British Standard, 2010)

\section{Penentuan parameter tanah}

Untuk melakukan input data ke dalam program elemen hingga 3D, perlu dilakukan parameter tanah yang cukup dan akurat agar program dapat menganalisa data sesuai dengan kondisi yang ada. Parameter tanah yang dibutuhkan antara lain.

\section{Kohesi}

Kohesi adalah gaya tarik menarik antar partikel yang sama/sejenis. Nilai kohesi dipengaruhi oleh sifat dan jenis tanah itu sendiri. Nilai kohesi dapat dilakukan dengan uji laboratorium melalui metode permeability test atau dengan metode USCS (unified soil classification system).

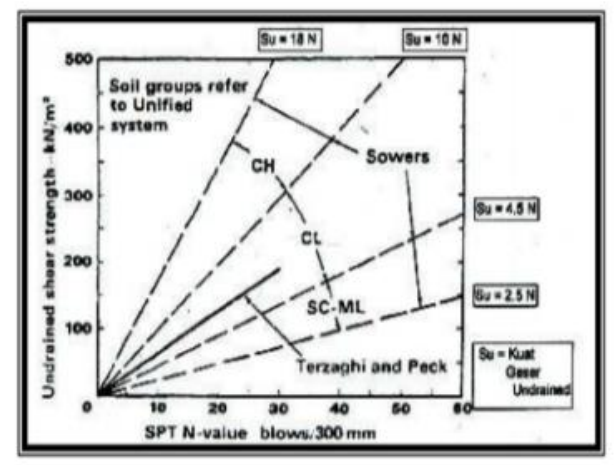

Gambar 4. Perkiraan hubungan N-SPT dengan nilai kohesi (Terzaghi and Peck, 1967)

\section{Modulus elastisitas}

Modulus elastisitas merupakan besaran nilai yang mengukur kemampuan deformasi elastis suatu bahan saat menerima beban. Faktor yang mempengaruhi modulis elastisitas tiang adalah mutu beton tiang tersebut. Penentuan nilai modulus elastisitas dapat menggunakan rumus berikut.

$$
E p=4700 x \sqrt{f^{\prime} c}
$$

dengan $\mathrm{E}_{\mathrm{p}}=$ modulus elastisitas tiang, $\mathrm{f} \mathrm{c} \mathrm{c}=$ mutu beton tiang 
Tabel 1. Persamaan modulus elastisitas untuk berbagai jenis tanah (Budhu, 2000)

\begin{tabular}{|c|c|c|c|}
\hline Soil & Spt & & $\mathrm{CPT}$ \\
\hline \multirow[t]{3}{*}{ sand (normally consolidated) } & $E s=500(N+15)$ & & Es $=2$ to $4 \mathrm{qc}$ \\
\hline & $E s=(15000$ to 22000$) \ln N$ & & $\mathrm{Es}^{\dagger}=\left(1+\mathrm{Dr}^{2}\right) \mathrm{qc}$ \\
\hline & Es $\S=(35000$ to 50000$) \log N$ & & \\
\hline Sand (saturated) & $E s=250(N+15)$ & & \\
\hline Sand (overconsolidated) & $\begin{array}{l}\mathrm{Es}_{\hat{\dagger} \dagger}=18000+750 \mathrm{~N} \\
\quad \mathrm{E}_{\mathrm{s}(\mathrm{OCR})}=\mathrm{E}_{\mathrm{s}(\mathrm{nc})}(\mathrm{OCR})^{1 / 2}\end{array}$ & & $\mathrm{Es}=6$ to $30 \mathrm{qc}$ \\
\hline \multirow[t]{3}{*}{ Gravelly sand and gravel } & Es $=1200(N+6)$ & & \\
\hline & $E s=600(N+6)$ & $\mathrm{N} \leq 15$ & \\
\hline & $E s=600(N+6)+2000$ & $\mathrm{~N}>15$ & \\
\hline Clayey Sand & $E s=320(N+15)$ & & Es $=3$ to $6 q \mathrm{c}$ \\
\hline Silty Sand & $E s=300(N+6)$ & & $\mathrm{Es}=1$ to $2 \mathrm{qc}$ \\
\hline Soft Clay & - & & Es $=3$ to $8 \mathrm{qc}$ \\
\hline \multirow{5}{*}{ Clay } & \multicolumn{3}{|c|}{ using the undrained shear strength $\mathrm{Su}$ in units of $\mathrm{Su}$} \\
\hline & & & Es $=100$ to 500 \\
\hline & tp $>30$ or organic & & \\
\hline & th $<30$ or stiff & & $\mathrm{Es}=500$ to 1500 \\
\hline & $\mathrm{E}_{\mathrm{s}(\mathrm{OCR})}=\mathrm{E}_{\mathrm{s}(\mathrm{nc})}(\mathrm{OCR})^{1 / 2}$ & & \\
\hline
\end{tabular}

\section{METODE PENELITIAN}

Alur atau tahapan dari penelitian ini tertera dalam bentuk diagram pada Gambar 5 .

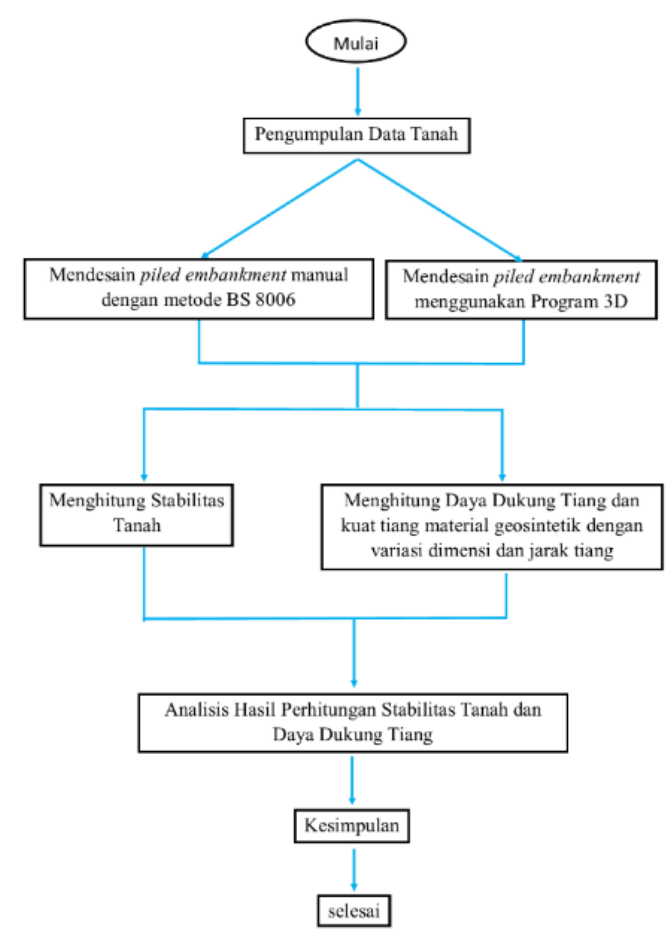

Gambar 5. Diagram alur penelitian 
Metode yang dilakukan dalam pengumpulan data ini adalah studi dokumen. Studi dokumen adalah salah satu jenis pengumpulan data yang meneliti berbagai macam dokumen untuk menjadi bahan analisis. Data yang dikumpulkan dalam skripsi ini adalah data dan klasifikasi tanah yang akan dianalisis.

Penelitian ini dilakukan dengan mengolah data-data yang dianalisis dengan program elemen hingga 3D untuk mendapatkan stabilitas tanah dan daya dukung tiang yang diperkuat dengan material geosintetik. Peneliti juga akan mengkombinasikan berbagai ukuran dan jarak antar tiang untuk mendapatkan hasil yang optimum.

\section{HASIL DAN PEMBAHASAN}

\section{Kondisi lapangan}

Kondisi lapangan terdiri dari 2 komponen, yaitu tanah timbunan dan tanah dasar. Data tanah dasar yang dianalisis adalah data tanah yang memiliki kondisi tanah paling buruk untuk menerima beban timbunan dari lima data tanah yang tersedia. Timbunan yang dianalisis terdiri dari beberapa jenis lapisan perkerasan jalan. 5 data boring log dan test laboratorium akan diwakili oleh data boring log yang terburuk. Tanah dasar yang akan dianalisis adalah data BH-03. Data tanah BH-03 yang akan dianalisis dan detail lapisan perkerasan jalan adalah sebagai berikut (Gambar 6-8).

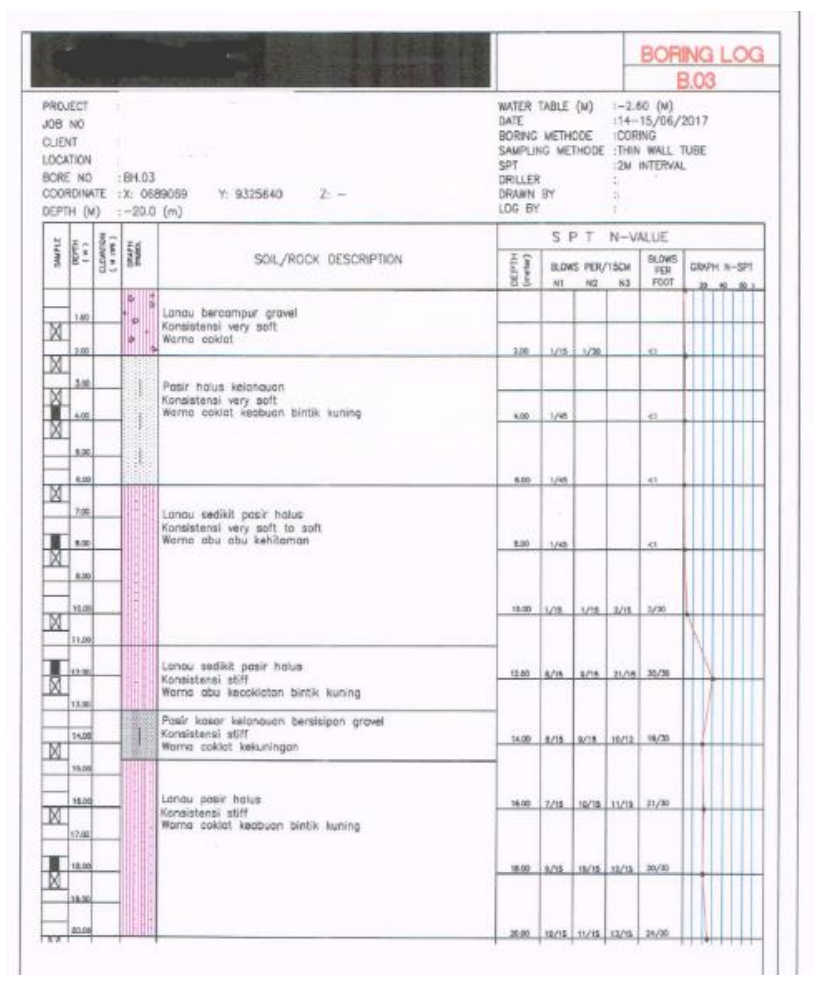

Gambar 6. Data boring log BH-03 (Sumber: Data Proyek) 


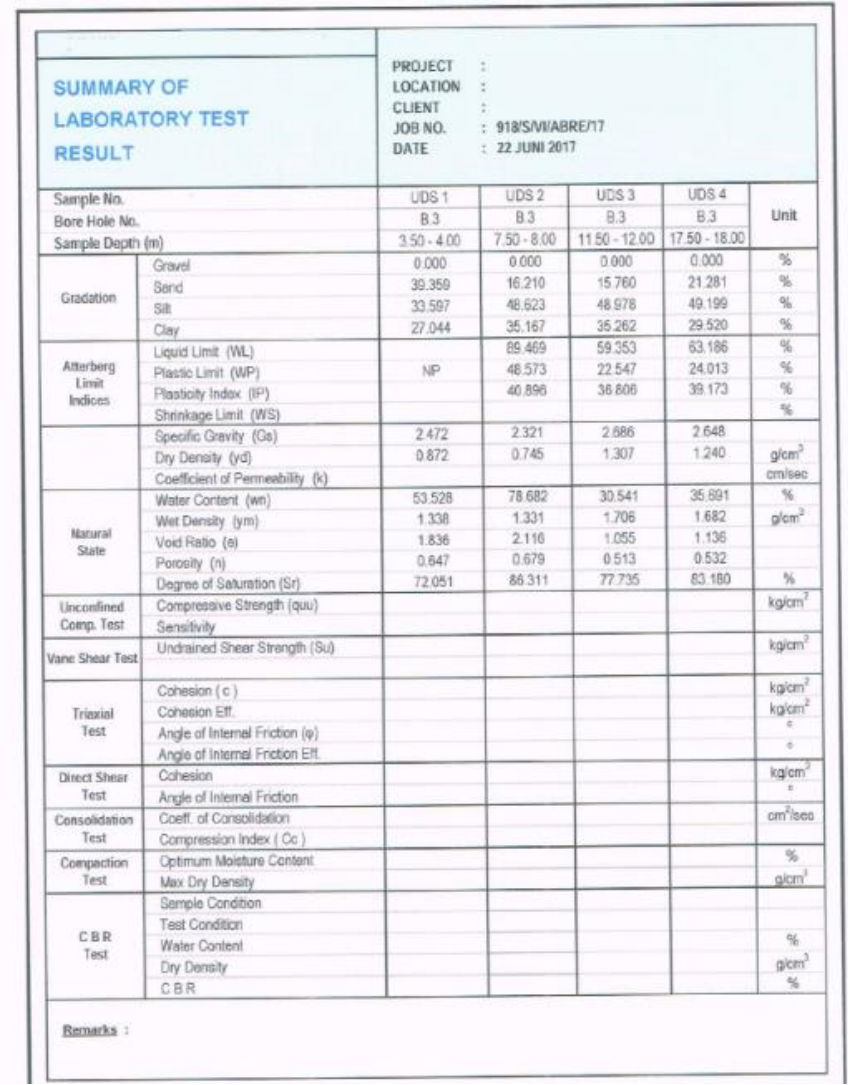

Gambar 7. Data summary B.3 (Sumber: Data Proyek)

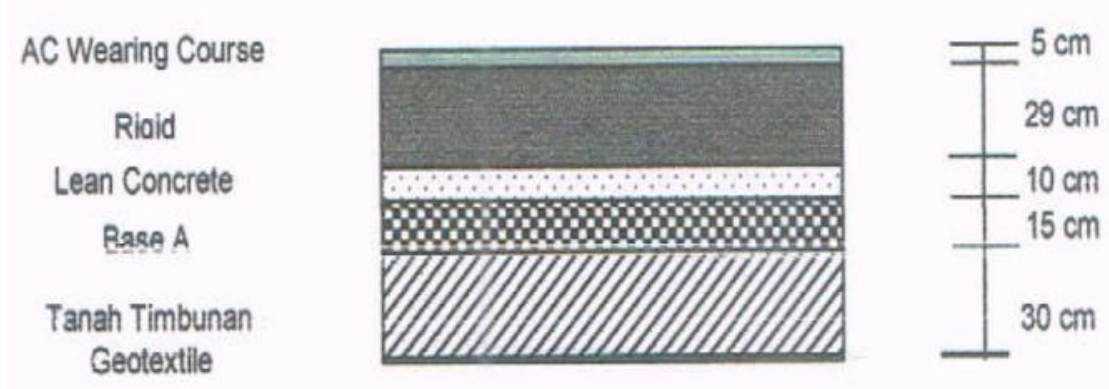

Gambar 8. Lapisan perkerasan jalan rencana (Sumber: Data Proyek)

Lapisan perkerasan jalan memiliki berbagai macam berat jenis, detail berat jenis masing - masing lapisan perkerasan jalan pada umumnya antara lain sebagai berikut (Tabel 2):

Tabel 2. Berat jenis tiap lapisan timbunan

\begin{tabular}{ccccc}
\hline No & Jenis Lapisan & $\begin{array}{c}\text { Tebal } \\
(\mathrm{cm})\end{array}$ & $\gamma$ sat $(\mathrm{kN} / \mathrm{m} 3)$ & $\gamma^{\prime}$ dry $(\mathrm{kN} / \mathrm{m} 3)$ \\
\hline 1 & AC Wearing Course & 5 & \multicolumn{3}{c}{23} \\
\hline 2 & Rigid Pavement & 29 & \multicolumn{2}{c}{24} \\
\hline 3 & Lean Concrete & 10 & & 22 \\
\hline 4 & Aggregate Base A & 15 & 20 & 19 \\
\hline 5 & Borrow material & 40 & 17 & 15 \\
\hline
\end{tabular}


Perhitungan manual dilakukan dengan cara merata - ratakan satu jenis timbunan untuk perhitungan manual. Hal ini dilakukan untuk mewakili lapisan timbunan dan mempermudah perhitungan manual. Selain beban pada timbunan, terdapat beban lalu lintar yang disebut beban tambahan. Beban lalu lintas diasumsikan sebesar $20 \mathrm{kPa}$. Beban lalu lintas ini dipakai untuk mensimulasi kendaraan yang melewati jalan tersebut.

\section{Analisis safety factor dengan program}

Sebelum melakukan analisis menggunakan tiang dan geosiintetik pada pelebaran jalan, kita harus melakukan analisa terhadap jalan yang sudah ada. Hal ini dilakukan untuk memastikan keamanan pada jalan. Dikarenakan data parameter tanah di bawah jalan tidak ada, maka parameter tanah yang akan dipakai adalah data tanah BH-03. Berikut merupakan hasil pada program saat belum ada pelebaran yang kita bisa lihat pada Gambar 9:

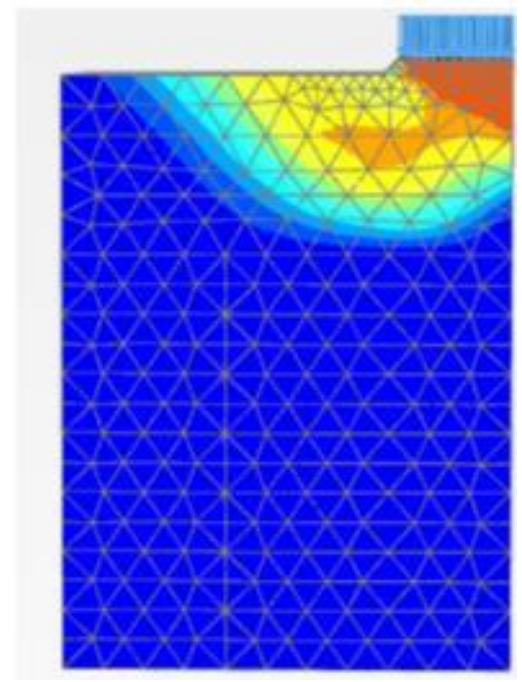

Gambar 9. Pola kelongsoran tanah pada jalan saat belum ada pelebaran

Setelah dilakukan analisa, Nilai safety factor terhadap timbunan tersebut adalah 1,025. Dapat dilihat nilai safety factor yang sangat kecil, sedangkan berdasarkan pengamatan di lapangan, konstruksi jalan tersebut dalam kondisi stabil sehingga perlu dilakukan analisa balik dengan mengasumsikan tanah dasar di bawah jalan eksisting mempunyai parameter yang lebih baik seperti pada Gambar 10.

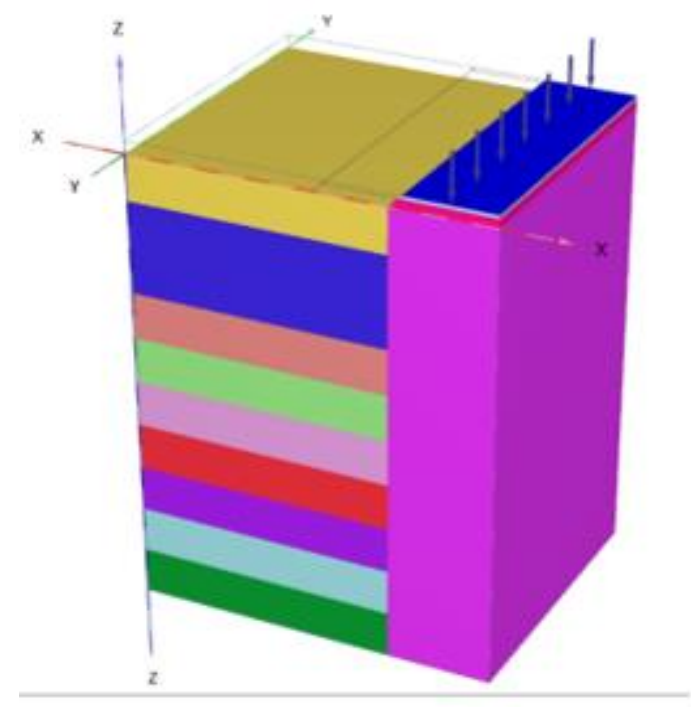

Gambar 10. Kondisi lapangan jalan tanpa pelebaran dengan tanah diperkeras

Setelah kalkulasi dilakukan, diperoleh nilai safety factor sebelum adanya pelebaran jalan. Nilai safety factor yang diperoleh pada timbunan tersebut adalah 1,88 . Hal ini menunjukkan bahwa asumsi parameter tanah pada jalan yang sudah ada cukup baik untuk mencegah kelongsoran pada jalan. 
Selanjutnya akan dilakukan kalkulasi untuk kondisi lapangan dengan pelebaran jalan. Setelah dilakukan analisa pada kondisi jalan tersebut, Kalkulasi dilakukan tanpa perkerasan apapun sehingga dapat diperoleh nilai safety factor awal sebelum diberikan tiang dan geosintetik. Nilai safety factor yang diperoleh pada timbunan tersebut adalah 1,428. Nilai safety factor ini yang akan menjadi kondisi awal dari Analisa perkuatan tiang dan geosintetik yang akan dilakukan, berikut merupakan pola kelongsoran yang terjadi pada kondisi lapangan saat tidak diberi perkuatan apapun yang dapat dilihat pada Gambar 11:

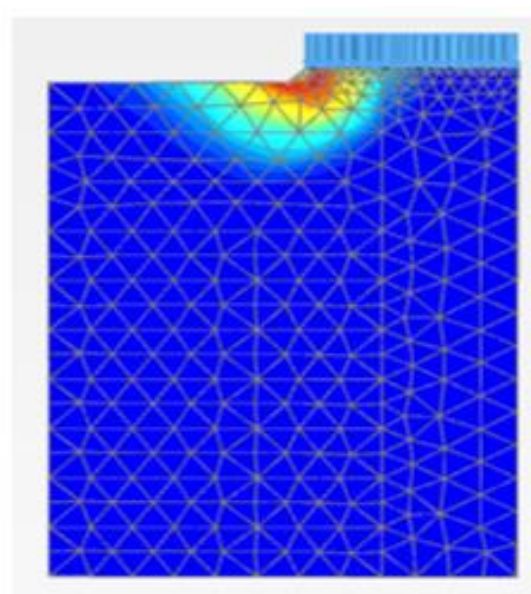

Gambar 11. Pola kelongsoran tanah tanpa diberikan perkuatan tiang dan geosintetik

Setelah diperoleh nilai safety factor pada kondisi awal, dilakukan analisis dengan memberikan tiang dan perkuatan geosintetik. Variabel yang digunakan pada analisa ini adalah dengan menggunakan variasi jarak antar tiang $0,5 \mathrm{~m}$, $1 \mathrm{~m}, 1,5 \mathrm{~m}$,variasi tiang $25 \mathrm{~cm}$ x $25 \mathrm{~cm}, 20 \mathrm{~cm}$ x $20 \mathrm{~cm}, 15 \mathrm{~cm}$ x $15 \mathrm{~cm}$, dan variasi kedalaman tiang $12 \mathrm{~m}$ dan 15 m. setelah melakukan kalkulasi dengan variasi - variasi tersebut, diperoleh nilai safety factor terhadap timbunan di atasnya. Berikut merupakan hasil analisa safety factor apabila timbunan diberikan perbaikan tanah yang dapat dilihat pada Tabel 3:

Tabel 3. Analisis output program terhadap kondisi lapangan

\begin{tabular}{ccccccc}
\hline No. & $\begin{array}{c}\text { Kedalaman } \\
\text { tiang }(\mathrm{m})\end{array}$ & $\begin{array}{c}\text { Ukuran tiang } \\
(\mathrm{m})\end{array}$ & $\begin{array}{c}\text { Ukuran pile } \\
\text { cap }(\mathrm{m})\end{array}$ & $\begin{array}{c}\text { Jarak antar } \\
\text { tiang }(\mathrm{m})\end{array}$ & SF & $\begin{array}{c}\text { Peningkatan safety factor } \\
\text { terhadap kondisi awal }\end{array}$ \\
\hline 1 & & & 0,5 & 3,09 & 1,662 \\
2 & 0,15 & 0,15 & 1 & 1,948 & 0,52 \\
3 & & & 1,5 & 1,827 & 0,399 \\
4 & & & 0,5 & 3,397 & 1,969 \\
5 & 12 & 0,2 & 0,2 & 1 & 2,162 & 0,734 \\
6 & & & & 1,5 & 1,891 & 0,463 \\
7 & & & 0,5 & 3,63 & 2,202 \\
8 & 0,25 & 0,25 & 1 & 2,388 & 0,96 \\
9 & & & 1,5 & 2,004 & 0,576 \\
\hline 10 & & & 0,5 & 3,17 & 1,742 \\
11 & & & 1 & 1,873 & 0,445 \\
12 & & 0,15 & 1,5 & 1,778 & 0,35 \\
13 & & & & 0,5 & 3,317 & 1,889 \\
14 & 15 & 0,2 & 0,2 & 1 & 1,955 & 0,527 \\
15 & & & & 1,5 & 1,834 & 0,406 \\
16 & & & & 0,5 & 3,67 & 2,242 \\
17 & & & 0,25 & 1 & 2,144 & 0,716 \\
18 & & & & 1,5 & 1,957 & 0,529 \\
\hline
\end{tabular}


jarak antar tiang, ukuran tiang dan kedalaman tiang. Berikut merupakan perubahan nilai safety factor terhadap perubahan ukuran tiang yang dapat dilihat pada Tabel 4:

Tabel 4. Nilai safety factor dengan variasi ukuran tiang

\begin{tabular}{ccccc}
\hline No. & Kedalaman tiang $(\mathrm{m})$ & Ukuran tiang $(\mathrm{m})$ & Jarak antar tiang $(\mathrm{m})$ & Safety factor \\
\hline 1 & 0,15 & & 3,09 \\
2 & 0,2 & 0,5 & 3,397 \\
3 & 0,25 & & 3,63 \\
4 & 0,15 & & 1,948 \\
5 & 12 & 0,2 & 1 & 2,162 \\
6 & 0,25 & & 2,388 \\
7 & 0,15 & & 1,827 \\
8 & 0,2 & 1,5 & 1,891 \\
9 & 0,25 & & 2,004 \\
\hline 10 & 0,15 & & 3,17 \\
11 & 0,2 & 0,5 & 3,317 \\
12 & 0,25 & & 3,67 \\
13 & 0,15 & & 1,873 \\
14 & 0,2 & 1 & 1,955 \\
15 & 0,25 & & 2,144 \\
16 & 0,15 & & 1,778 \\
17 & & 0,2 & 1,5 & 1,834 \\
18 & & 0,25 & & 1,957 \\
\hline
\end{tabular}

Dengan melihat perubahan ukuran tiang dengan nilai safety factor, dapat disimpulkan bahwa perubahan ukuran tiang dapat mempengaruhi nilai safety factor yang didapat, semakin besar ukuran tiang maka akan semakin besar nilai safety factor yang didapat. Untuk mempermudah analisa, Tabel 4 diubah menjadi bentuk grafik yang dapat dilihat pada Gambar 12:

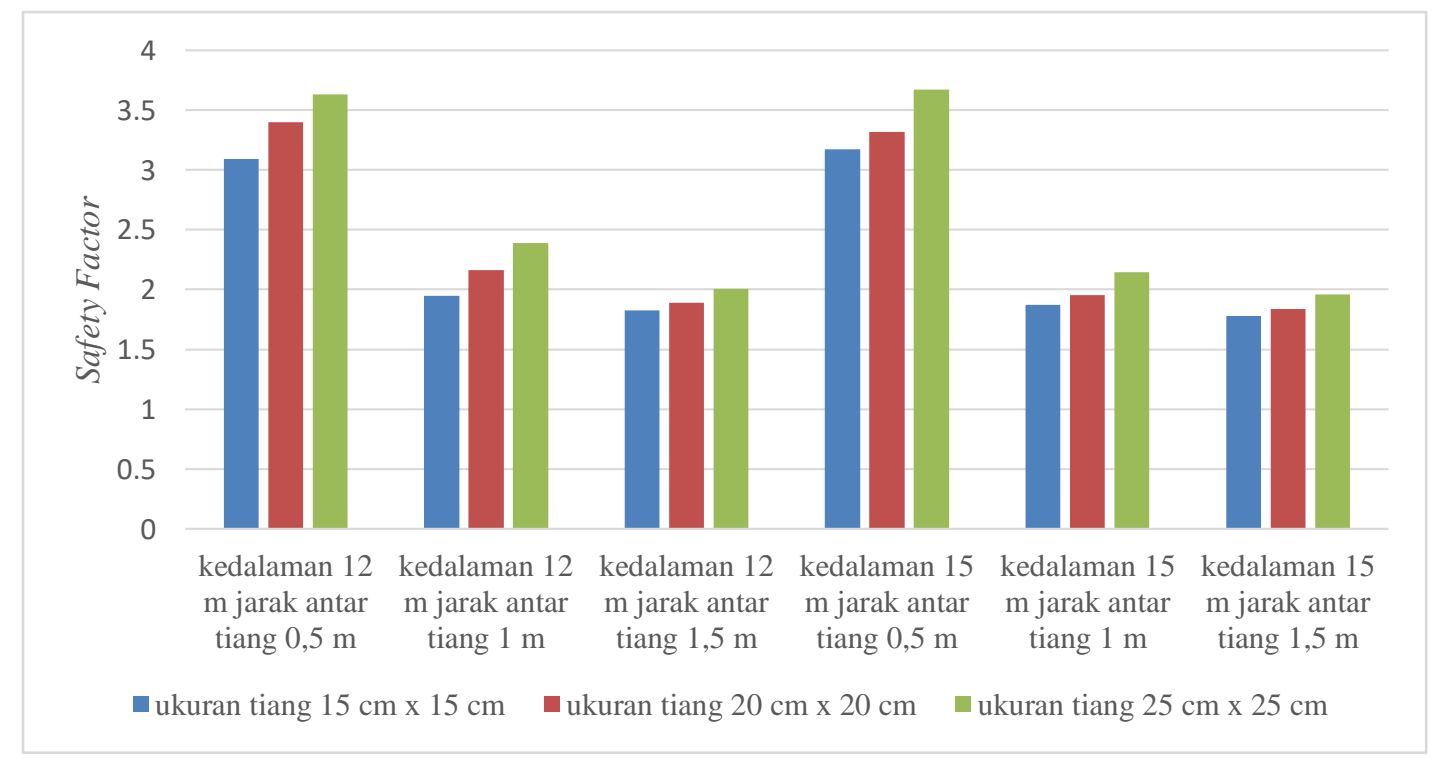

Gambar 12. Nilai safety factor terhadap perubahan ukuran tiang 
Tabel 5. Nilai safety factor dengan variasi jarak antar tiang kedalaman

\begin{tabular}{ccccc}
\hline No & $\begin{array}{c}\text { Kedalaman tiang } \\
(\mathrm{m})\end{array}$ & $\begin{array}{c}\text { Jarak antar tiang } \\
(\mathrm{m})\end{array}$ & $\begin{array}{c}\text { Ukuran tiang } \\
(\mathrm{m})\end{array}$ & Safety factor \\
\hline 1 & & & 0,5 & 3,09 \\
2 & & 0,15 & 1 & 1,948 \\
3 & & & 1,5 & 1,827 \\
4 & & & 0,5 & 3,397 \\
5 & 12 & 0,2 & 1 & 2,162 \\
6 & & & 1,5 & 1,891 \\
7 & & & 0,5 & 3,63 \\
8 & & 0,25 & 1 & 2,388 \\
9 & & 1,5 & 2,004 \\
\hline 10 & & & 0,5 & 3,17 \\
11 & & 0,15 & 1 & 1,873 \\
12 & & & 1,5 & 1,778 \\
13 & & & 0,5 & 3,317 \\
14 & 15 & 0,2 & 1 & 1,955 \\
15 & & & 1,5 & 1,834 \\
16 & & & 0,5 & 3,67 \\
17 & & 0,25 & 1 & 2,144 \\
18 & & & 1,5 & 1,957 \\
\hline
\end{tabular}

Berdasarkan Tabel 5, dapat disimpulkan bahwa semakin kecil jarak antar tiang, maka nilai safety factor semakin besar. Hal ini terjadi disebabkan oleh persebaran beban pada tiang semakin baik jika jarak antar tiang semakin mengecil. Berikut merupakan grafik yang memperlihatkan nilai safety factor terhadap perbedaan jarak tiang yang dapat dilihat pada Gambar 13:

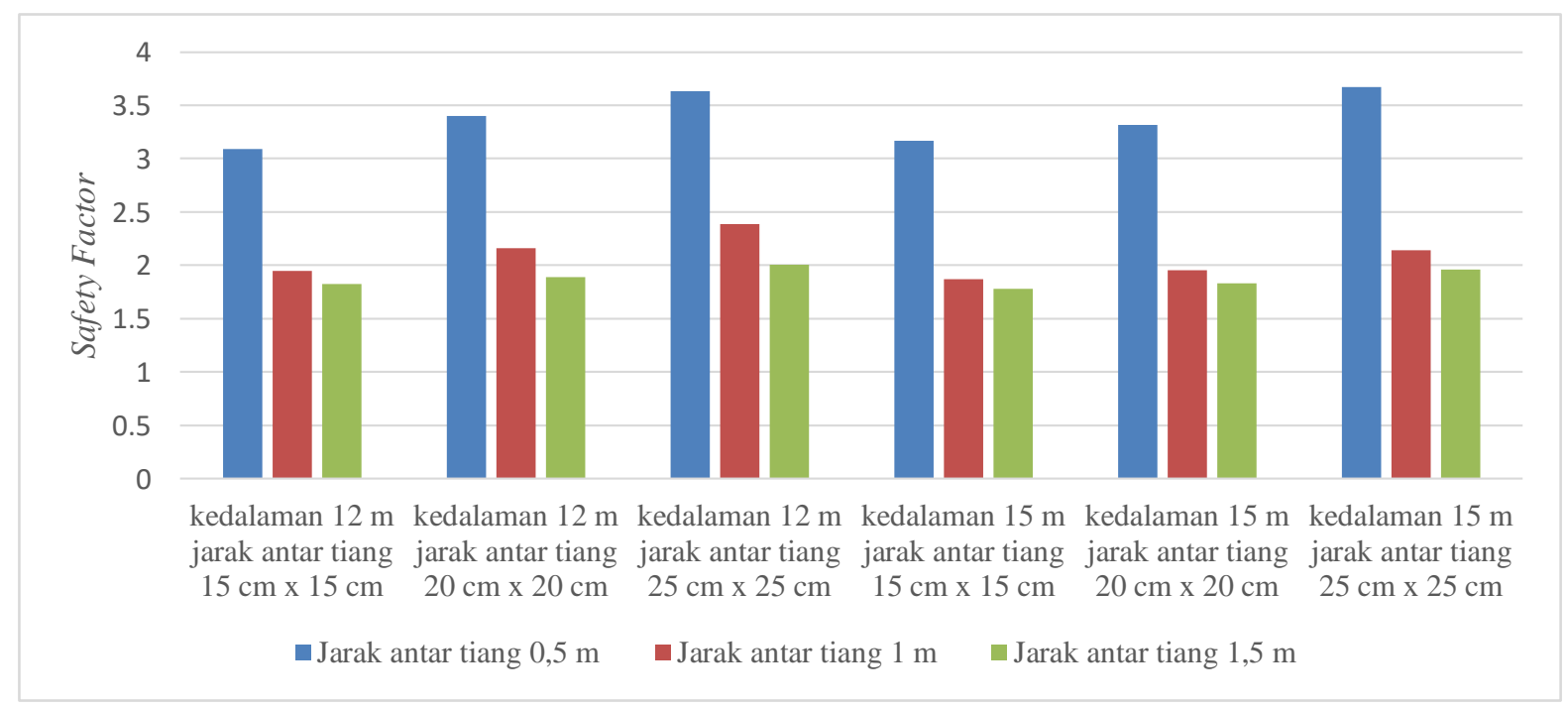

Gambar 13. Grafik safety factor terhadap perubahan jarak antar tiang 

Geosintetik Menggunakan Program Elemen Hingga

Tabel 6. Nilai safety factor dengan variasi kedalaman tiang

\begin{tabular}{ccccc}
\hline No & $\begin{array}{c}\text { Kedalaman tiang } \\
(\mathrm{m})\end{array}$ & $\begin{array}{c}\text { Ukuran tiang } \\
(\mathrm{m})\end{array}$ & $\begin{array}{c}\text { Jarak antar tiang } \\
(\mathrm{m})\end{array}$ & Safety factor \\
\hline 1 & 12 & & 0,5 & 3,09 \\
2 & 15 & & & 3,17 \\
3 & 12 & 0,15 & 1 & 1,948 \\
4 & 15 & & & 1,873 \\
5 & 12 & & 1,5 & 1,827 \\
6 & 15 & & 0,5 & 1,778 \\
\hline 7 & 12 & & & 3,397 \\
8 & 15 & & 1 & 3,317 \\
9 & 12 & 0,2 & & 2,162 \\
10 & 15 & & 1,5 & 1,955 \\
11 & 12 & & \multirow{2}{*}{0,891} \\
12 & 15 & & & 1,834 \\
\hline 13 & 12 & & 1 & 3,63 \\
14 & 15 & & & 2,678 \\
15 & 12 & 0,25 & 1,5 & 2,144 \\
16 & 15 & & & 2,004 \\
17 & 12 & & & \\
18 & 15 & & & \\
\hline
\end{tabular}

Berdasarkan Tabel 6, dapat dilihat bahwa perubahan nilai safety factor terhadap kedalaman tiang tidak terlalu signifikan. Berikut merupakan grafik yang menunjukan nilai safety factor terhadap kedalaman tiang yang dapat dilihat pada Gambar 14:

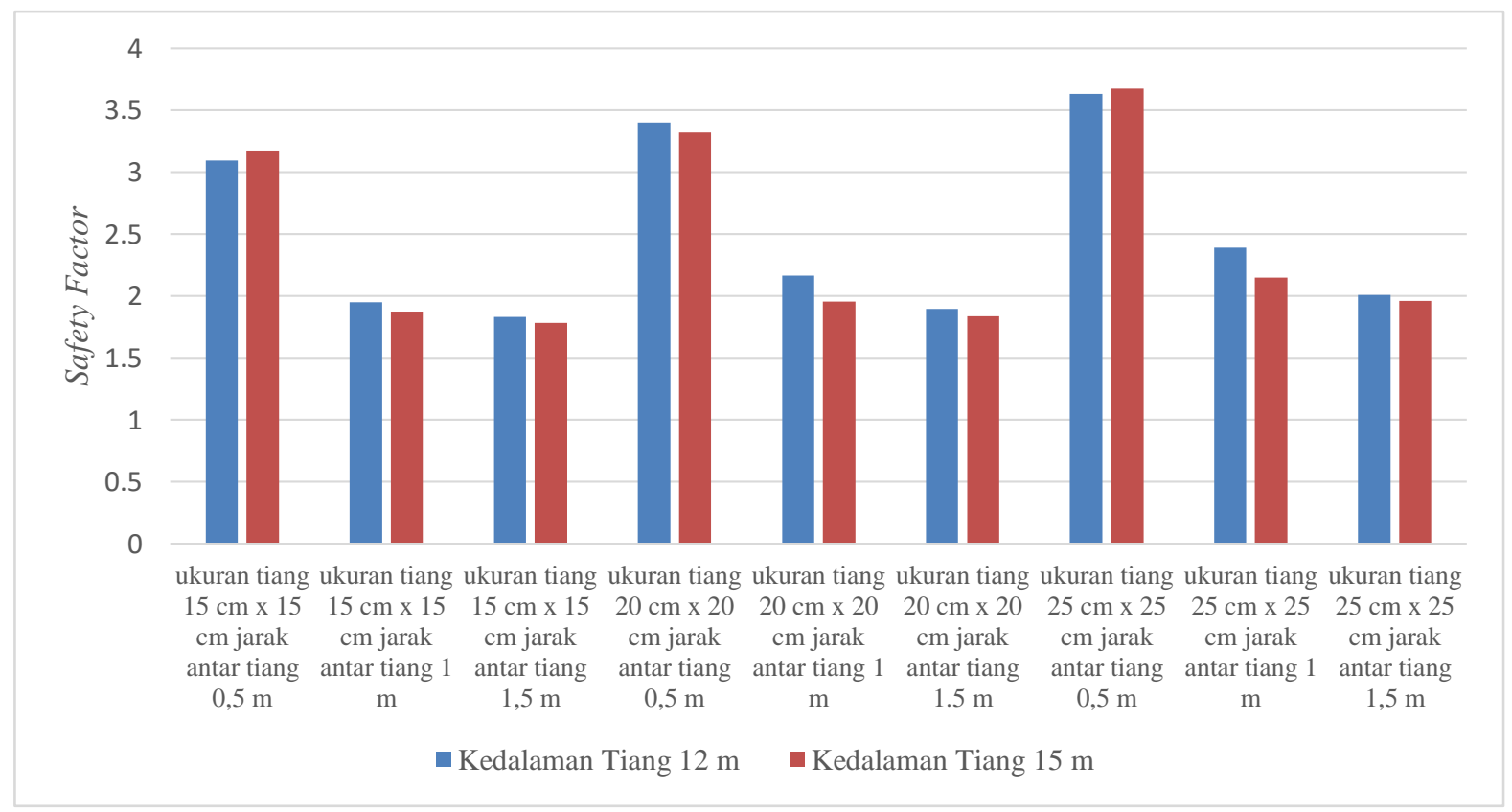

Gambar 14. Grafik safety factor terhadap perubahan kedalaman tiang

Perbedaan nilai safety factor yang tidak terlalu jauh ini dapat disebabkan karena pola kelongsoran yang terjadi tidak terlalu mempengaruhi tiang. Berikut merupakan pola kelongsoran yang terjadi saat pelebaran jalan diberikan perkuatan tiang dan geosintetik yang dapat dilihat pada Gambar 15: 


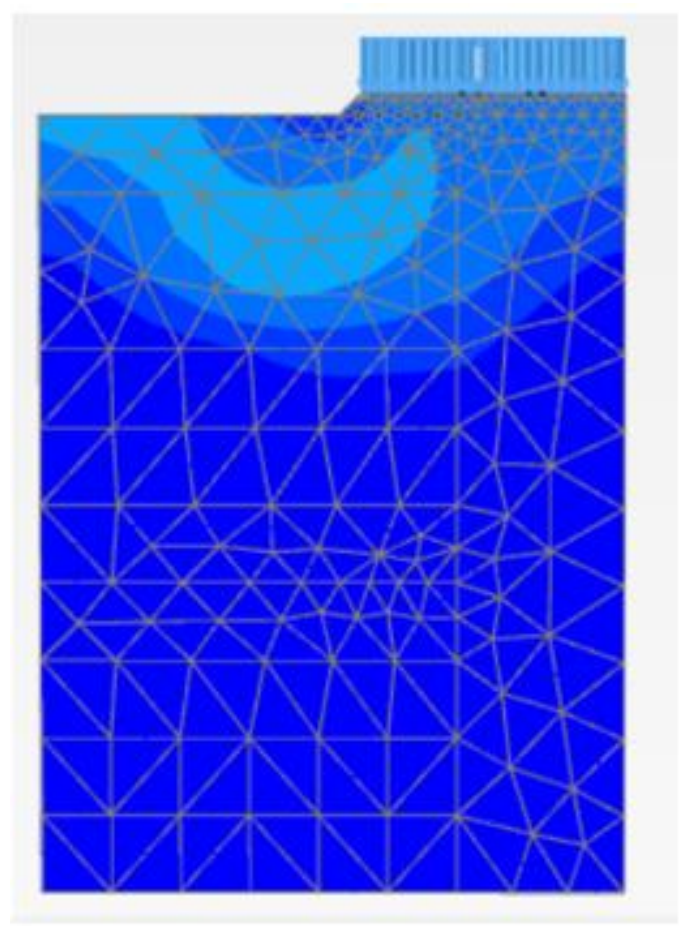

Gambar 15. Pola kelongsoran saat diberikan perkuatan dan geosintetik

\section{Analisa kuat tarik geosintetik}

Setelah melakukan analisis dengan menggunakan program, perlu dilakukan perhitungan untuk menentukan kuat tarik geosintetik yang dibutuhkan. Perhitungan akan dilakukan dengan 2 metode, yaitu dengan menggunakan perhitungan manual dan perhitungan dengan program.

Setelah melakukan perhitungan manual dan melakukan analisa pada program, maka diperoleh hasil tegangan maksimum yang terjadi pada geosintetik. Jika digabungkan, maka dapat dilihat perbedaan dari hasil perhitungan manual dan program yang dapat dilihat pada Tabel 7:

Tabel 7. Perbandingan perhitungan manual dengan output program

\begin{tabular}{ccccc}
\hline $\begin{array}{c}\text { Ukuran } \\
\text { tiang } \\
(\mathrm{m})\end{array}$ & $\begin{array}{c}\text { Ukuran pile } \\
\text { cap } \\
(\mathrm{m})\end{array}$ & $\begin{array}{c}\text { Jarak antar tiang } \\
(\mathrm{m})\end{array}$ & $\begin{array}{c}\text { Kuat tarik manual } \\
(\mathrm{kN} / \mathrm{m})\end{array}$ & $\begin{array}{c}\text { Kuat tarik } \\
\text { geosintetik hasil } \\
\text { program }(\mathrm{kN} / \mathrm{m})\end{array}$ \\
\hline \multirow{3}{*}{0,15} & 0,15 & 0,5 & 27,916 & 26,32 \\
& & 1 & 133,718 & 51,77 \\
& & 1,5 & 295,969 & 73,34 \\
\hline \multirow{3}{*}{0,2} & 0,2 & 0,5 & 25,078 & 24,69 \\
& & 1 & 97,217 & 64,57 \\
& & 1,5 & 216,017 & 87,6 \\
\hline \multirow{3}{*}{0,25} & 0,25 & 0,5 & 23,642 & 19,28 \\
& & 1 & 74,762 & 59,26 \\
& & 1,5 & 167,381 & 75,99 \\
\hline
\end{tabular}

Dengan melihat hasil di atas, dapat dilihat adanya perbedaan antara kuat tarik geosintetik hasill perhitungan program dengan perhitungan BS 8006. Perbedaan kuat tarik geosintetik hasil perhitungan BS 8006 lebih besar jika dibandingkan dengan perhitungan hasil program. Perbedaan ini disebabkan karena perhitugan dengan metode $B S$ 8006 tidak memperhitungkan tanah dasar di bawah geosintetik. Pada program, tanah dasar yang berada di bawah geosintetik membantu mengurangi nilai tegangan pada geosinetik. 


\section{KESIMPULAN DAN SARAN}

\section{Kesimpulan}

1. Kuat tarik geosintetik berdasarkan perhitungan metode elemen hingga dengan perhitungan manual $B S 8006$ (2010) memiliki perbedaan yang cukup besar. Perbedaan ini akan semakin besar jika jarak antar tiang semakin besar. Hal ini disebabkan karena pada metode $B S$ 8006, metode ini tidak mempertimbangkan tanah dasar yang berada di bawah geosintetik. Hal ini dapat dilihat pada ukuran tiang 0,2 dimana pada jarak antar tiang $0,5 \mathrm{~m}$ kuat tarik geosintetik manual adalah $25,078 \mathrm{kN} / \mathrm{m}$ dan pada hasil program sebesar $24,69 \mathrm{kN} / \mathrm{m}$, lalu pada jarak antar tiang $1 \mathrm{~m}$ kuat tarik geosintetik manual adalah $97,217 \mathrm{kN} / \mathrm{m}$ dan pada hasil program sebesar $64,57 \mathrm{kN} / \mathrm{m}$ sedangkan jarak antar tiang $1,5 \mathrm{~m}$ kuat tarik geosintetik manual adalah $216,017 \mathrm{kN} / \mathrm{m}$ dan pada hasil program sebesar $87,6 \mathrm{kN} / \mathrm{m}$.

2. Geotekstil sangat membantu dalam mengurangi kelongsoran yang terjadi pada tanah, karena geotekstil membantu dalam menyalurkan beban yang bekerja kepada tiang yang ada di bawahnya. Hal ini dapat dilihat dari peningkatan safety factor setidaknya sebesar 24,5\% terhadap kondisi awal yaitu 1,428 menjadi 1,778 pada tiang $15 \mathrm{~cm}$ x $15 \mathrm{~cm}$ dengan jarak $1,5 \mathrm{~m}$.

3. Peningkatan safety factor terhadap kedalaman tiang tidak terlalu signifikan, hal ini dapat disebabkan karena kedalaman tiang tidak terlalu mempengaruhi kuat tarik geosintetik yang terjadi terhadap beban di atasnya.

4. Berdasarkan analisis yang dilakukan, jika dilihat dari beban yang bekerja pada timbunan, tiang persegi dengan ukuran $15 \mathrm{~cm} \times 15 \mathrm{~cm}$, dengan jarak antar tiang $0,5 \mathrm{~m}$ dan kedalaman $12 \mathrm{~m}$ dan kuat tarik geosintetik $27,916 \mathrm{kN} / \mathrm{m}$, dapat menyalurkan beban dengan sangat baik.

\section{Saran}

1. Dari hasil analisis yang dilakukan, disarankan melakukan analisis geosynthetic-reinforce piled supported embankment dengan metode perhitungan yang lain termasuk analisis yang memperhitungkan penurunan tanah pada konstruksi, karena hal ini dapat menambahkan ketepatan dalam memperhitungkan kuat tarik geosintetik yang diperlukan pada kostruksi.

2. Dapat digunakan tiang dengan ukuran dan bentuk tiang yang lain untuk mendapatkan hasil yang lebih optimal, ukuran tiang dan bentuk tiang yang optimal dapat didapatkan dengan trial dan error.

\section{DAFTAR PUSTAKA}

Boogert. Piled Embankments with Geosynthetic. Delft: Delft University of Technology, 2011.

British Standard. Code of Practice for Strengthened/Reinforced Soil and Other Fills. Londons: BSI Standards Publication, 2010.

Budhu, Muni. Soil Mechanics. 3nd. New York: John Wiley \& Sons, 2000.

Gangakhedkar, R. Geosynthetic Reinforced Pile Supported Embankment. University of Florida, 2004.

Terzaghi, Karl and Ralph B Peck. Soil Mechanics In Engineering practice. 3nd. New York: John Wiley \& Sons,

Zhuang, Yan. Numerical Modelling of Arching in Piled Embankments Including The Effects of Reinforcement and Subsoil. 2009. 